\title{
Archaeological Sites Along Cuthand Creek and the Sulphur River in the Mid-Sulphur River Basin, Red River County, Texas
}

Timothy K. Perttula

Heritage Research Center, Stephen F. Austin State University

Gary W. Cheatwood

Follow this and additional works at: https://scholarworks.sfasu.edu/ita

Part of the American Material Culture Commons, Archaeological Anthropology Commons, Environmental Studies Commons, Other American Studies Commons, Other Arts and Humanities Commons, Other History of Art, Architecture, and Archaeology Commons, and the United States History Commons

Tell us how this article helped you.

This Article is brought to you for free and open access by the Center for Regional Heritage Research at SFA ScholarWorks. It has been accepted for inclusion in Index of Texas Archaeology: Open Access Gray Literature from the Lone Star State by an authorized editor of SFA ScholarWorks. For more information, please contact cdsscholarworks@sfasu.edu. 


\section{Archaeological Sites Along Cuthand Creek and the Sulphur River in the Mid-Sulphur River Basin, Red River County, Texas \\ Creative Commons License \\ (c) (1) (8)}

This work is licensed under a Creative Commons Attribution-NonCommercial 4.0 International License 


\title{
Archaeological Sites Along Cuthand Creek and the Sulphur River in the Mid-Sulphur River Basin, Red River County, Texas
}

\author{
Timothy K. Perttula and Gary W. Cheatwood
}

\section{INTRODUCTION}

The Cuthand Creek and Little Mustang Creek drainage basins in the mid-Sulphur River basin are in the Post Oak Savannah of East Texas (Figure 1). Prehistoric archaeological sites are abundant in both basins and along the Sulphur River, dating from as early as Paleoindian times to the Late Caddo periods (see Bousman et al. 1988; Cheatwood 1988; Gaither et al. 1991). Nevertheless, this area remains poorly known and there have been few professional archaeological investigations conducted here. In this article, we present information on a range of prehistoric sites and associated artifact assemblages known along Cuthand Creek and the Sulphur River in the mid-Sulphur River Basin, in Red River County, Texas. The artifacts that are discussed herein are in the collections of the junior author.

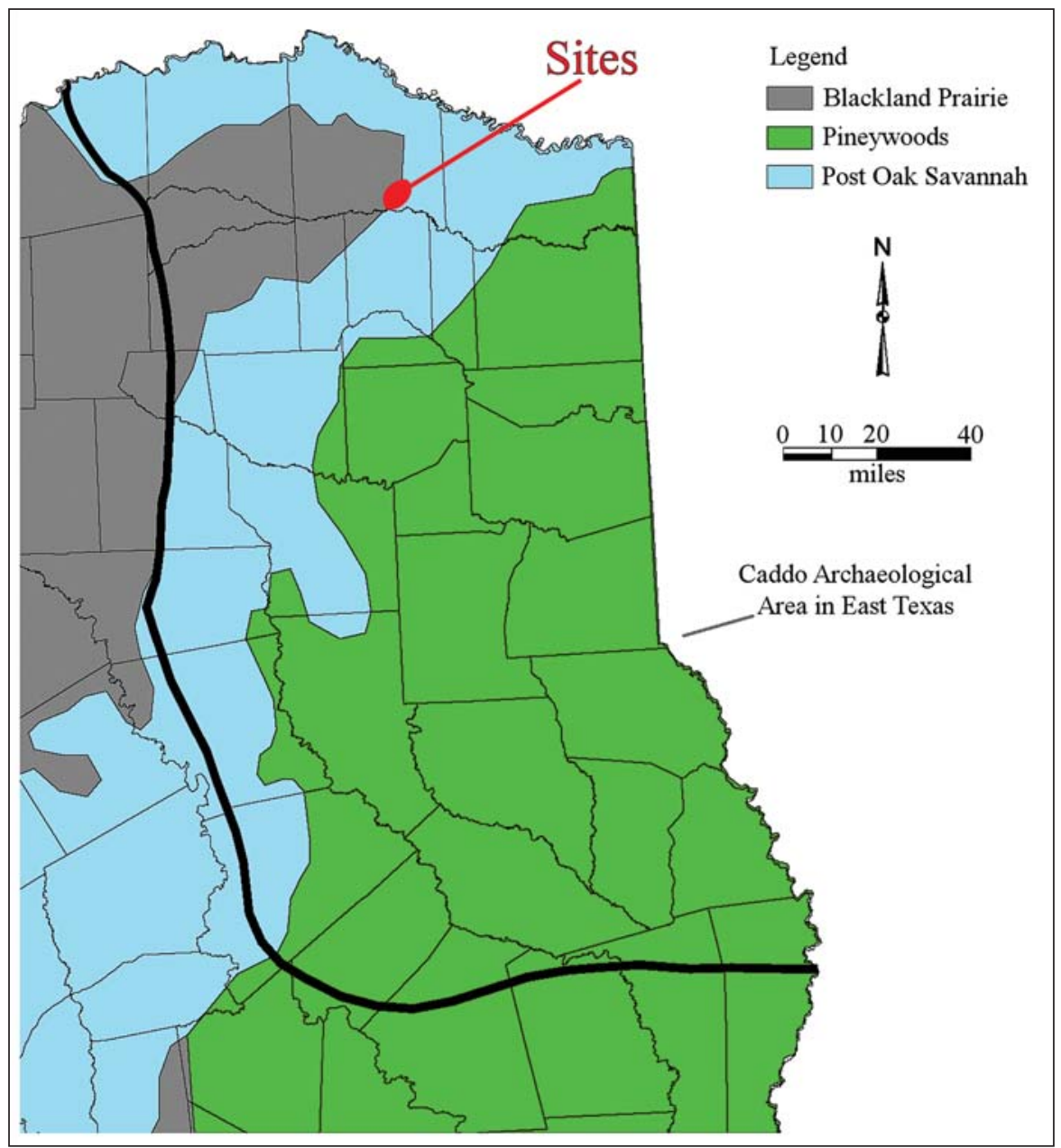

Figure 1. Cuthand Creek and Little Mustang Creek drainage basins in East Texas. Figure prepared by Lance K. Trask. 


\section{Sulphur River Sites}

\section{Mustang Bluffs (41RR40)}

This site appears to have been occupied during the Woodland period (ca. 500 B.C.-A.D. 800). It is located on an alluvial terrace overlooking the confluence of Little Mustang Creek and the Sulphur River. Artifacts from the Mustang Bluffs site include a Gary, var. Camden dart point (see Schambach 1982, 1998), thick $(9.3-10.7 \mathrm{~mm}$, with a mean thickness of $9.77 \mathrm{~mm})$ grog-tempered Williams Plain sherds, and one grog-tempered sherd with rows of punctations.

\section{Cheatwood Lake (41RR190)}

The Cheatwood Lake site is on an alluvial terrace overlooking Cheatwood Lake, part of an old channel of the Sulphur River, and just below the confluence of Little Mustang Creek with the Sulphur River. The old channel periodically dries up, but when it is full of flood waters, it erodes the edge of the terrace, eroding archaeological materials along a ca. $600 \mathrm{~m}$ stretch along Cheatwood Lake.

Chipped stone lithic artifacts from the site include quartzite lithic debris and a few chipped stone tools. These are represented by thick early stage biface fragments, and end scraper, and a straight stem dart point of Late Archaic age.

There is a substantial Caddo ceramic assemblage from the Cheatwood Lake site. Plain rims are from grog, grog-bone, and bone-tempered bowls, carinated bowls, bottles, and everted rim jars; they have standing to slightly everted rims with rounded, rounded-exterior folded, and flat lips. One rim sherd is lip notched and another has an exterior thickened rim. The notching of the lips of vessels at the sole rim decoration is an apparently distinctive decorative method in a number of different Caddo communities of different ages in East Texas. The earliest assemblages, dating from ca. A.D. 900-1300, with lip notched vessels occur in the upper Red, upper and middle Sabine, and in the Angelina River basins (Perttula 2015:Figure 9). Middle Caddo communities where lip notched ceramics were made include the same previously mentioned assemblages, as well as sites in the Big Cypress Creek basin. By post-A.D. 1400 times until the early $18^{\text {th }}$ century, ceramic assemblages with lip notched vessels occur more regularly in the upper Neches, middle Red River, middle Sabine, and the Angelina River basin.

Plain body sherds $(n=183)$ are from grog-tempered $(n=82,45$ percent), grog-bone-tempered $(n=79$, 43 percent), bone-tempered ( $\mathrm{n}=17,9$ percent), sandy paste sherds ( $\mathrm{n}=4,2.2$ percent) with a grayish-black paste, and shell-tempered ( $\mathrm{n}=1,0.5$ percent) vessels. Perttula et al. (2012) reviewed the age and distribution of shell-tempered ceramics in Caddo sites across the southern Caddo area. In general, shell-tempered ceramics were made by East Texas Caddo potters after ca. A.D. 1300, particularly in McCurtain phase sites along the middle reaches of the Red River and the lower Kiamichi River in southeastern Oklahoma (Perttula 2015:Figure 12; see also Selden et al. 2014:Figure 4). In East Texas McCurtain phase ceramic assemblages, the proportions of shell-tempered sherds ranges from 93-100 percent. Caddo sites dating between ca. A.D. 1400-1680 with considerable amounts of shell-tempered ceramic sherds are found at just a few sites in the upper Sulphur and the mid-Red River basin in East Texas. By contrast, high proportions of shelltempered sherds in ceramic assemblages are relatively common in post-A.D. 1700 Historic Caddo sites only in the upper Sabine, the Big Cypress Creek basin, and in two locales on the Red River, both upstream and downstream from the McCurtain phase sites.

The mean thickness of these body sherds ranges from $6.28 \mathrm{~mm}$ to $7.9 \mathrm{~mm}$; the bone-tempered vessels have thinner vessel walls than do the grog-tempered vessel sherds. The six base sherds (flat disks with no inflection points, ranging in thickness from $10-14 \mathrm{~mm})$ are from grog- $(n=2)$, grog-bone- $(n=3)$, and bonetempered $(n=1)$ vessels. 
Common decorated sherds from utility ware jars in the ceramic assemblage have horizontal rows of fingernail or tool punctations on vessel rims, with vessel bodies either plain or brushed. Several rim sherds have organic residue preserved on interior vessel surfaces. Other utility wares are from Maydelle Incised everted rim jars with diagonal incised lines as well as late variant Dunkin Incised (see Jelks 1961:Plate 8h) vessels. Other incised sherds have vertical incised lines, including one with a horizontal appliqued lug on the vessel lip, as well as broad horizontal incised lines on a bowl, and a possible Maydelle Incised rim (see Suhm and Jelks 1962:103) with cross-hatched lines and lugs placed at rim peaks. One incised-punctated sherd has an incised panel filled with punctations, while a rim sherd from an everted rim jar has horizontal incised lines above a row of triangular tool punctations..

There are also Pease Brushed-Incised sherds that have horizontal incised lines on the rim and vertical brushing marks on the vessel body (see Suhm and Jelks 1962:Plate 60g). Also common in the ceramic assemblage are Pease Brushed-Incised everted rim jars that have diagonal incised lines on the rim, a horizontal band of closely-spaced punctations at the lip and at the rim-body juncture; the vessel bodies were brushed. Pease Brushed-Incised or McKinney Plain jar sherds (see Suhm and Jelks 1962:97) have appliqued fillets on the rim as well as roughened or faintly brushed marks on the rim; another McKinney Plain jar has a roughened body. Sherds from at least one everted rim jar have brushed marks on the vessel rim and body.

One shell-tempered neck banded sherd is from a Nash Neck Banded jar. Neck banded jars were a common utility ware in a number of ancestral Caddo communities occupied after ca. A.D. 1300 in East Texas (Perttula 2015:Figure 10), including both grog-bone and shell-tempered varieties. The highest proportions (23.6-79.6 percent of the decorated sherd assemblage) of neck banded sherds (shell-tempered) occur in ca. A.D. 1400-1680 McCurtain phase assemblages on the middle reaches of the Red River. Shell-tempered neck banded sherds (Nash Neck Banded) are also found in high percentages at other sites on the same age in other Red River communities both upstream and downstream from the McCurtain phase sites; both grog/ bone and shell-tempered neck banded sherds are found in these areas. In other locales across East Texas, neck banded wares are almost exclusively grog/bone-tempered. These wares are found in sites in the upper Neches and upper Sabine in Frankston (ca. A.D. 1400-1650) and Titus phase (ca. A.D. 1430-1680) contexts and in Titus phase ceramic assemblages in the Big Cypress Creek basin. This ware has been classified as La Rue Neck Banded.

Fine ware sherds from the Cheatwood Lake site are from carinated bowls and bottles. Carinated bowl sherds have parallel engraved lines with pendant triangles, broad curvilinear lines, and possible scroll elements. Bottle sherds have curvilinear engraved lines. There are Sanders Plain grog-bone-tempered bowl sherds with interior and exterior red-slipped surfaces.

\section{Cuthand Creek Sites}

\section{RR170}

This site has several archaeological components preserved in a floodplain knoll about $0.5 \mathrm{~km}$ south of an old channel of Cuthand Creek. There are midden deposits at the northern end of the knoll, and animal bone was noted in gopher mounds.

The first of the components may date to the latter part of the Woodland period (ca. A.D. 200-700) based on the occurrence of Gary, var. Camden dart points made from local quartzite (see Schambach 1982, 1998). There is also an Early Caddo period (ca. A.D. 1000-1200) occupation with a Spiro Engraved bottle sherd (see Suhm and Jelks 1962:Plate 74f), a punctated body sherd, and a bone-tempered sherd with a poorly preserved red slip. The last component dates to the $19^{\text {th }}$ century and is marked by one cut nail (manufactured between 1820-1891). 


\section{RR171}

Late Caddo style Talco arrow points dating from ca. A.D. 1600-1680 have been found at 41RR171. The site is on an upland ridge slope south of an old channel of Cuthand Creek.

\section{Crossed Arrows Ranch (41RR172 and 41RR173)}

Both sites on the Crossed Arrows Ranch are on sandy knolls on a broad (600 x $300 \mathrm{~m})$ alluvial terrace about $0.5 \mathrm{~km}$ south of an old channel of Cuthand Creek. There are springs present along the margins of the terrace.

There are three midden deposits on 41RR172 and one midden deposit at 41RR173; the latter overlooks a natural spring pond. Each of the middens have Caddo ceramics, and there is a Woodland period Gary, var. Camden dart point made from quartzite on 41RR173. Other chipped stone lithics include both early and late stage biface fragments made from local quartzite as well as lithic debris from local raw materials as well as Ouachita Mountains chert (Woodford, Johns Valley, and Big Fork) and novaculite from Red River gravels (see Banks 1990).

Caddo ceramic sherds from the Crossed Arrows Ranch site are from grog and grog-bone-tempered vessels. Plain body sherds have a mean body wall thickness of $7.6 \mathrm{~mm}$. Decorated sherds have rows of fingernail punctations, incised line elements, and engraved sherds with red-slipped surfaces. One Sanders Engraved red-slipped sherd has cross-hatched engraved lines (see Suhm and Jelks 1962:137).

Caddo sites of uncertain age and character are present at 41RR174 and 41RR175 on alluvial knolls in the Cuthand Creek floodplain; an old channel of the creek runs both north and east of the sites. These two sites are just east of the Crossed Arrow Ranch sites.

\section{Old Blizzard Place (41RR176)}

The Old Blizzard Place is on an alluvial terrace (310 feet amsl) about $1 \mathrm{~km}$ south of an old channel of Cuthand Creek. There are ca. 1880s-1940s midden deposits from the occupation by the Blizzard family, as well as a possible ancestral Caddo occupation. This occupation has plain grog-tempered body sherds and one grog-tempered punctated sherd.

\section{$41 R R 177$}

This prehistoric site is on an alluvial terrace (305 feet amsl) $0.5 \mathrm{~km}$ south of an old channel of Cuthand Creek. There are no midden deposits apparent at the site, and the few Caddo vessel sherds are plain grogtempered body sherds (mean thickness of $7.35 \mathrm{~mm}$ ) and one Middle Caddo period style Sanders Plain bowl or carinated bowl red-slipped sherd (5.5 mm thick).

\section{RR196}

This site has been exposed in floodplain clays along a channelized section of Cuthand Creek, about $13 \mathrm{~km}$ south of Clarksville, Texas. The collections from the site are comprised of 114 ceramic sherds from several different vessels. Most of the sherds are from the undecorated body portion of a jar tempered with grog and bone. This jar has a flat disk base (13 mm in thickness) and relatively thick body walls (9-11 mm). Other plain sherds are from grog, bone, and grog-bone-tempered vessels, including a carinated bowl. A plain rim is exterior thickened.

The decorated sherds include red-slipped rim and base sherds, and the rim (grog-bone-tempered) has 
an exterior thickened rim. Other decorated sherds include a bone-grog-tempered body sherd with parallel brushing marks, and a body sherd from a Pease Brushed-Incised vessel that has parallel brushing marks on either side of a straight appliqued fillet.

\section{Drew Place (41RR197)}

The Drew Place site is on two floodplain knolls ca. $1 \mathrm{~km}$ north of Cuthand Creek. Pickett Creek, a tributary to Cuthand Creek, runs just south of the site. Both knolls are capped with midden deposits with preserved faunal remains. Several Caddo burials with associated funerary offerings (ceramic vessels) were looted from the southern knoll in the late 1980s.

Chipped stone artifacts in the collections from the site include lithic debris of both local quartzite as well as non-local novaculite; the novaculite has been heat-treated. There are 33 sherds from ancestral Caddo ceramic vessels tempered with both grog $(n=19)$, bone $(n=5)$, and grog-bone $(n=3)$; six other sherds have a sandy paste but no apparent temper inclusions. Most of the sherds are plain body sherds with body walls that range in thickness from $5.7-8.5 \mathrm{~mm}$; a few are from bowls or carinated bowls with burnished interior and/or exterior surfaces. Decorated sherds in the collection are red-slipped (Sanders Plain), tool punctated, punctated-appliqued (possibly from a Pease Brushed-Incised jar), and a diagonal incised rim (vertical profile and a rounded lip).

\section{Brooks Place (41RR198)}

The Brooks Place site is on an alluvial terrace south of an old channel of Cuthand Creek. In the 1930s, Caddo burials with associated ceramic vessels of an unknown age were dug at the site.

\section{SUMMARY AND CONCLUSIONS}

Prehistoric archaeological sites are known to be common in the Cuthand Creek and Little Mustang Creek areas of the mid-Sulphur River basin in the Post Oak Savannah in modern-day Red River County, Texas. The sites discussed in this article were identified by the junior author, who lives in Bogota, Texas, in the county. Putting archaeological information about these sites on record serves to provide useful data on the native history of this part of East Texas, still relatively unknown to the archaeological community.

The available archaeological information from these particular sites indicates that they were occupied as early as the Late Archaic period (ca. 5000-2500 years B.P.), but both Woodland (ca. 2500-1150 years B.P.) and post-A.D. 800 Caddo tradition sites are well represented. Three sites have Woodland period components and there are 13 ancestral Caddo components at the other sites, Almost 50 percent of these components are from Middle Caddo period occupations (ca. A.D. 1200-1400), one component has an Early Caddo period occupation (ca. A.D. 1000-1200), and 15 percent have Late Caddo (ca. A.D. 1400-1680) components. Several components have a temporally unidentified Caddo occupation. The concentration of Middle Caddo components in this part of the Sulphur River basin is notable (see also Gaither et al. 1991), which suggests that post-A.D. 1200 Caddo farmers had successfully settled in this part of East Texas.

\section{REFERENCES CITED}

Banks, L.

1990 From Mountain Peaks to Alligator Stomachs: A Review of Lithic Sources in the Trans-Mississippi South, the Southern Plains, and Adjacent Southwest. Memoir No. 4. Oklahoma Anthropological Society, Norman. 
Bousman, C. B., M. B. Collins, and T. K. Perttula

1988 Quaternary Geomorphology at Cooper Basin: An Archeological Inquiry. Reports of Investigations No. 55. Prewitt and Associates, Inc., Austin.

Cheatwood, G.

1988 Notes on the Stratigraphic Position of Archeological Remains in the Sulphur River Valley, Red River County, Texas. In Quaternary Geomorphology at Cooper Basin: An Archeological Inquiry, by C. B. Bousman, M. B. Collins, and T. K. Perttula, pp. 139-143. Reports of Investigations No. 55. Prewitt and Associates, Inc., Austin.

Gaither, S., T. K. Perttula, and G. Cheatwood

1991 The Cheatwood Place (41RR181), a Midden Mound along Little Mustang Creek, Red River County, Texas. Caddoan Archeology Newsletter 2(1):21-28.

Jelks, E. B.

1961 Excavations at Texarkana Reservoir, Sulphur River, Texas. River Basin Survey Papers No. 21. Bureau of American Ethnology, Smithsonian Institution, Washington, D.C.

Perttula, T. K.

2015 East Texas Caddo Ceramic Sherd Database. Journal of Northeast Texas Archaeology 51:1-46.

Perttula, T. K., M. B. Trubitt, and J. S. Girard

2012 The Use of Shell-Tempered Pottery in the Caddo Area of the Southeastern United States. Southeastern Archaeology 30(2):242-267.

Schambach. F. F.

1982 An Outline of Fourche Maline Culture in Southwest Arkansas. In Arkansas Archeology in Review, edited by N. L. Trubowitz and M. D. Jeter, pp. 132-197. Research Series No. 15. Arkansas Archeological Survey, Fayetteville.

1998 Pre-Caddoan Cultures of the Trans-Mississippi South. Research Series 53. Arkansas Archeological Survey, Fayetteville.

Selden, R. Z. Jr., T. K. Perttula, and D. L. Carlson

2014 INAA and the provenance of shell-tempered sherds in the ancestral Caddo region. Journal of Archaeological Science 47:113-120.

Suhm, D. A. and E. B. Jelks (editors)

1962 Handbook of Texas Archeology: Type Descriptions. Special Publication No. 1, Texas Archeological Society, and Bulletin No. 4, Texas Memorial Museum, Austin. Reprinted in 2009, Gustav's Library, Davenport, Iowa. 